\title{
Fermented Soybean Protein Beverage
}

National Cancer Institute

\section{Source}

National Cancer Institute. Fermented Soybean Protein Beverage. NCI Thesaurus. Code C71541.

A fermented soybean-derived phytochemical beverage with potential antineoplastic activity. Fermented soybean protein beverage is reported to exhibit immunostimulatory, anti-viral, pro-apoptotic, anti-angiogenic, anti-proliferative, and anti-inflammatory activities and to enhance the cytotoxic effects of natural killer (NK) cells. The fermentation process is reported to hydrolyze many soybean proteins into amino acids and nitrogen-rich compounds and to protect and enhance the activities of isoflavones such as genistein, protease inhibitors, saponins, phytosterols, inositol hexaphosphate, and other beneficial dietary nutrients and micronutrients found in soybeans. 